\title{
Inventory of fishes in the upper Pelus River (Perak river basin, Perak, Malaysia)
}

\author{
Mat Esa Mohd Ikhwanuddin, ${ }^{1}$ Mohammad Noor Azmai Amal, ${ }^{1}$ Azizul Aziz, ${ }^{1}$ Johari Sepet, ${ }^{1}$ \\ Abdullah Talib, ${ }^{1}$ Muhammad Faiz Ismail, ${ }^{1}$ Nor Rohaizah Jamil ${ }^{2}$
}

1 Department of Biology, Faculty of Science, Universiti Putra Malaysia, 43400 UPM Serdang, Selangor, Malaysia. 2 Department of Environmental Sciences, Faculty of Environmental Studies, Universiti Putra Malaysia, 43400 UPM Serdang, Selangor, Malaysia.

Corresponding author: Mohammad Noor Azmai Amal, mnamal@upm.edu.my

\begin{abstract}
The upper Pelus River is located in the remote area of the Kuala Kangsar district, Perak, Malaysia. Recently, the forest along the upper portion of the Pelus River has come under threat due to extensive lumbering and land clearing for plantations. Sampling at 3 localities in the upper Pelus River at 457, 156 and $89 \mathrm{~m}$ above mean sea level yielded 521 specimens representing 4 orders, 11 families, 23 genera and 26 species. The most abundant species was Neolissochilus hexagonolepis, followed by Homalopteroides tweediei and Glyptothorax major. The fish community structure indices was observed to increase from the upper to lower portion of the river, which might reflect differences in water velocity.
\end{abstract}

\section{Key words}

Faunal inventory; freshwater; species diversity; tropical forest.

\section{Introduction}

The Pelus River catchment in Perak state, northern Malaysia, is a subdrainage of the upper Perak river basin, which flows from its source near the Thailand border, southwards through Perak state. The Pelus River is discharged into the Perak river basin about $10 \mathrm{~km}$ downstream of Chenderoh Lake. Total catchment size for Pelus River is estimated at $170 \mathrm{~km}^{2}$, with the stream length approximately $17 \mathrm{~km}$. The average annual rainfall depth in this catchment area is around $2025 \mathrm{~mm}$ (Toriman 2010). The rivers of this drainage have relatively short tributaries. Their gradients in the upper courses are correspondingly steep. Some rivers can drop to more than $50 \mathrm{~m}$, resulting in magnificent waterfalls (Toriman 2010). Forest covers an extensive area and envelops entire settlements and agriculture land use. Palm oil and rubber plantations are present in downstream area, while sundry cultivation is observed in the settlement from downstream upwards (Toriman et al. 2008).

Most of the previous fish diversity studies conducted in Perak state was made in Temengor Lake, Perak River, and lakes located along the Perak river basin (Hashim et al. 2012). The fish diversity of the highland zones, such as the upper Pelus river basin, was rarely investigated (Toriman et al. 2008). Recently, extensive lumbering and land clearing activity has been observed along the upper portion of this river, which might become a threat to the pristine water quality and fish population of this isolated area (Toriman et al. 2008). Thus, this study aims to sur- 


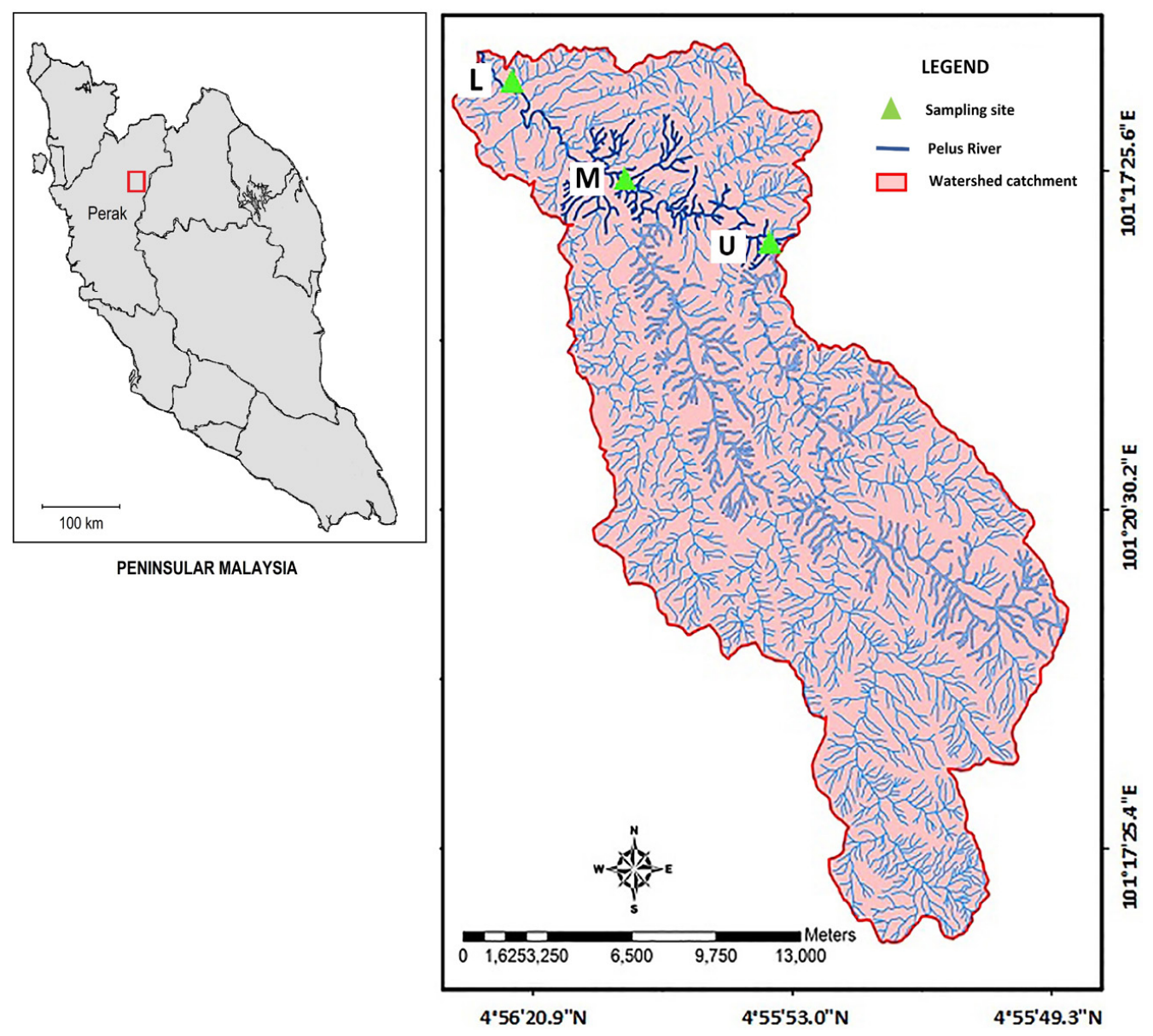

Figure 1. Location of sampling sites in upper Pelus River, Perak river basin, Perak, Malaysia. L) lower portion; M) middle portion; U) upper portion.

vey the current fish species inhabiting the upper Pelus river basin. The inventory of fishes herein presented can serves as a guideline to manage, protect and conserve this upper river portion in the near future.

\section{Methods}

Study site. Fishes were sampled from 3 localities in upper Pelus River (Fig. 1), specifically at a lower site at $89 \mathrm{~m}$ above sea level (a.s.1.) (0457'22.6" N, 101 $\left.{ }^{\circ} 15^{\prime} 06.1^{\prime \prime} \mathrm{E}\right)$; a middle site at $156 \mathrm{~m}$ a.s.1. $\left(04^{\circ} 56^{\prime} 16.5^{\prime \prime} \mathrm{N}, 101^{\circ} 17^{\prime} 25.4^{\prime \prime} \mathrm{E}\right)$, and an upper site at $457 \mathrm{~m}$ a.s.1. $\left(04^{\circ} 56^{\prime} 25.9^{\prime \prime} \mathrm{N}, 101^{\circ}\right.$ 18'02.1" E) (Fig. 2). Samples were taken at each site in 3 different seasons: dry (June 2014), wet (August 2014), and moderately wet (April 2015).

The lower site was characterized by low gradient bank slope, the lack of macrophytes, small rocks and sand substratum, and shallow, slightly turbid and slow flowing water. The middle and upper sites are characterized by high gradient slope, the lack of macrophytes, small to large rock and sand substratum, and shallow to deep, slightly turbid to clear water. However, the water flow in the upper site was faster compared to the middle site.

Fish sampling. Specimens were collected with fish electro shocker (DOF, Malaysia), with working current ranging from $50-500 \mathrm{~V}$. At each site, sampling covers a

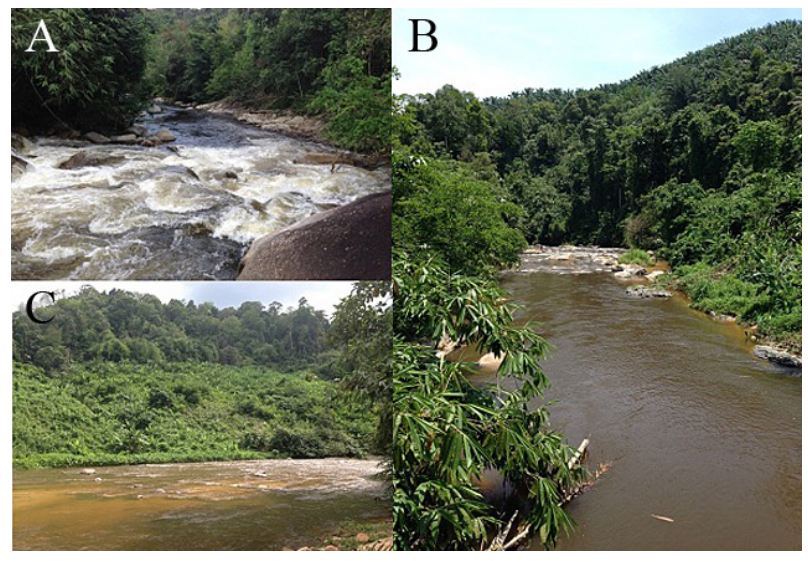

Figure 2. Sampling sites in the Pelus river basin, Perak, Malaysia. A. Upper portion. B. Middle portion. C. Lower portion.

stretch of $200 \mathrm{~m}$ along the river, and up to $10 \mathrm{~m}$ from the river bank. The sampling sites were consistently chosen for all sampling seasons. Electrofishing was done by wading and applying the same catching effort for each site, spending approximately $2 \mathrm{~h}$ at each site.

Specimens that could confidently be identified were recorded, and if the fish still alive, they were released. Those that could not be identified in the field were fixed in a $10 \%$ formalin solution, and later transferred to a $70 \%$ ethanol solution. Specimen identification was based on 
Haslawati et al. (2007), Ambak et al. (2010), and Zulkafli et al. (2014). All specimens were cataloged in the Universiti Putra Malaysia Zoology Museum, Department of Biology, Faculty of Science, Universiti Putra Malaysia. Valid species name were consulted in Kottelat (2013). Threat status was obtained from the IUCN Red List of Threatened Species (http://www.iucnredlist.org, accessed 18 September 2016).

The diversity, evenness, and richness indexes at each sampling site were calculated based on Shannon and Weaver (1963), Pielou (1969) and Margalef (1958), respectively. The indexes are presented in the form of the mean of 3 different sampling seasons in order to understand the whole fish community structures of this upper river portion.

\section{Results}

A total of 521 specimens were caught, representing 26 species from 23 genera of 11 families, distributed in 4 orders (Table 1). Photographs of the collected fishes are presented in Figure 3. The mean of Shannon-Weaver Diversity, Pielou's Evenness and Margalef's Richness indexes showed increasing pattern from the upper to lower sampling sites of the river (Table 1). The lists of species are provided below.

\section{Cypriniformes}

Homaloptera orthogoniata Vaillant, 1902

Homaloptera orthogoniata Vaillant 1902: 122.

Material examined. Table 1; Figure 3a.

Homaloptera orthogoniata, $H$. confuzona and $H$. parclitella are similar, but $H$. orthogoniata can be differentiated from those species by a few characters. The most useful of these are the dark markings extending from the snout over the dorsal surface, forming a series of saddle-shaped blotches. Homaloptera orthogoniata has 3 saddles, while $H$. parclitella has only 2 , and $H$. confuzona has up to 4 irregularly shaped markings, which are normally restricted to the upper half of the body. This species inhabit forested streams with black waters (Kottelat et al. 1993), usually with some current and wood debris (Kottelat and Widjanarti 2005).

Homalopteroides tweediei (Herre, 1940)

Homaloptera tweediei Herre 1940: 7.

Material examined. Table 1; Figure $3 \mathrm{~b}$.

This species possesses $33-37$ lateral line scales; 4 simple and 10 branched pectoral-fin rays; 4 or 5 scale rows between the lateral line and dorsal-fin origin; faint dorsal and lateral blotches with a dark stripe along the lateral line, while dorsal and lateral blotches faint with a slightly darker mid-lateral stripe; pectoral fins extending past-pelvic-fin base. Diagnosis characters (Alfred 1969): 32-36 + 2 lateral line scales, 3-5 unbranched and 7-11 branched pectoral-fin rays (vs 37-39+ 2 lateral line scales, and 5 or 6 unbranched and 10-12 branched pectoral-fin rays in $H$. smithi). This species can be found in moderate currents with living and dead vegetation. They feed on small aquatic insects and zooplankton (Rainboth 1996).

Barbodes binotatus (Valenciennes, 1842)

Barbodes binotatus Valenciennes 1842: 168.

Barbus maculatus var. hagenii Popta 1911: 9.

Barbus simplex Schreitmüller 1935: 508

Material examined. Table 1; Figure 3c.

This species has 4 spines on dorsal fin, 8 soft dorsalfin rays, 3 spines on anal fin, and 5 soft anal-fin rays. The lateral line is complete at $4 \frac{1}{2}$ scales between lateral line and dorsal fin origin; 4 barbels; last simple dorsal-fin ray is bony and serrated behind; 1 large blotch at anterior base of dorsal-fin ray and a round spot in the middle of caudal peduncle (dark, wedge-shaped blotch on each flank, beneath the dorsal-fin in B. banksi). This species can be found in middle to bottom depths in fairly shallow waters where it feeds on zooplankton, insect larvae and some vascular plants (Rainboth 1996).

Barbodes lateristriga (Valenciennes, 1842)

Barbodes lateristriga Valenciennes 1842: 161.

Barbus zelleri Ahl 1937: 115.

Material examined. Table 1.

Barbodes lateristriga can be identified by the lateral markings usually forming a solid stripe and no streak extending from the operculum (vs prominent row of dark spots along the lateral line, plus a short and horizontally orientated streak extending from the upper part of the operculum in B. kuchingensis). This species usually inhabit clear mountain streams strewn with rocks and boulders, and frequently found below waterfalls (Roberts 1989). This species feeds on worms, crustaceans, insects and plant matter (Mills and Vevers 1989).

Crossocheilus atrilimes Kottelat, 2000

Crossocheilus atrilimes Kottelat 2000: 39 .

Material examined. Table 1; Figure 3d.

Crossocheilus atrilimes is characterized by the following combination of characters: midlateral stripe extending to posterior border of median caudal-fin rays; 1 or 2 rows of faint dark spots along scale rows below lateral line; $1-1 \frac{1}{2}$ scale rows between anus and anal-fin origin; body depth at $23.8-26.4 \%$ of standard length (SL) and single pair of rostral barbels. Notwithstanding, $C$. langei, the most similar congener is differentiated from C. atrilimes by having eyes reddish-golden above the pupil and white below; 2 pairs of barbels; the lateral line is essentially straight and passes through the centre of the dark body stripe; the fins are brownish. Crossocheilus atrilimes and $C$. oblongus are sympatric, but $C$. oblongus inhabits swifts, rapids and torrents water, whereas $C$. atrilimes is found in slower water habitats (Kottelat 2000).

Devario regina (Fowler, 1934)

Danio peninsulae Smith 1945: 98.

Danio regina Fowler 1934b: 342.

Material examined. Table 1; Figure 3e.

This species is recognized by having a total of $13 \mathrm{soft}$ dorsal-fin rays and 16-17 soft anal-fin rays. The body has typical cyprinid shape, being sleek and slender, with a 


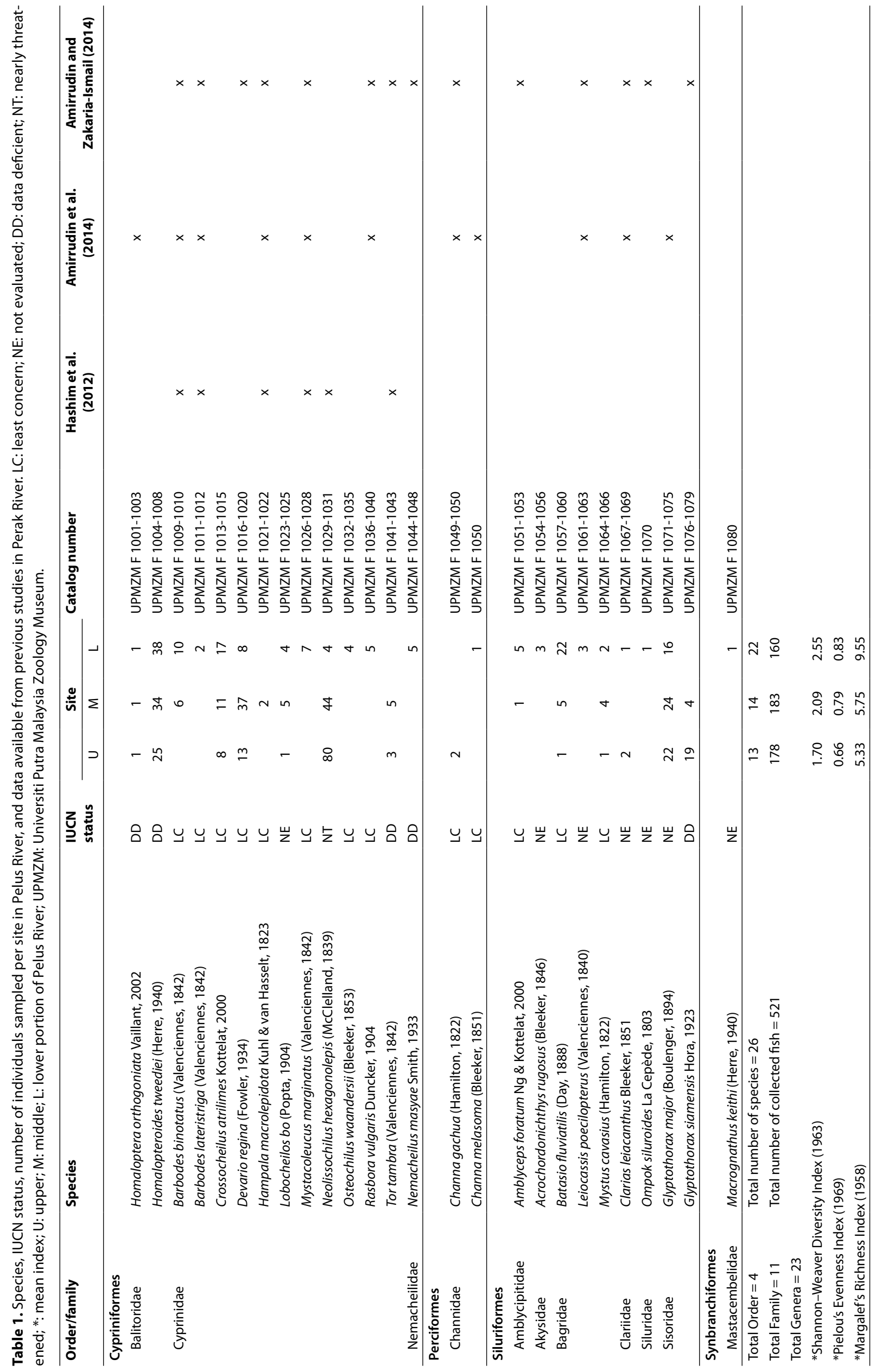



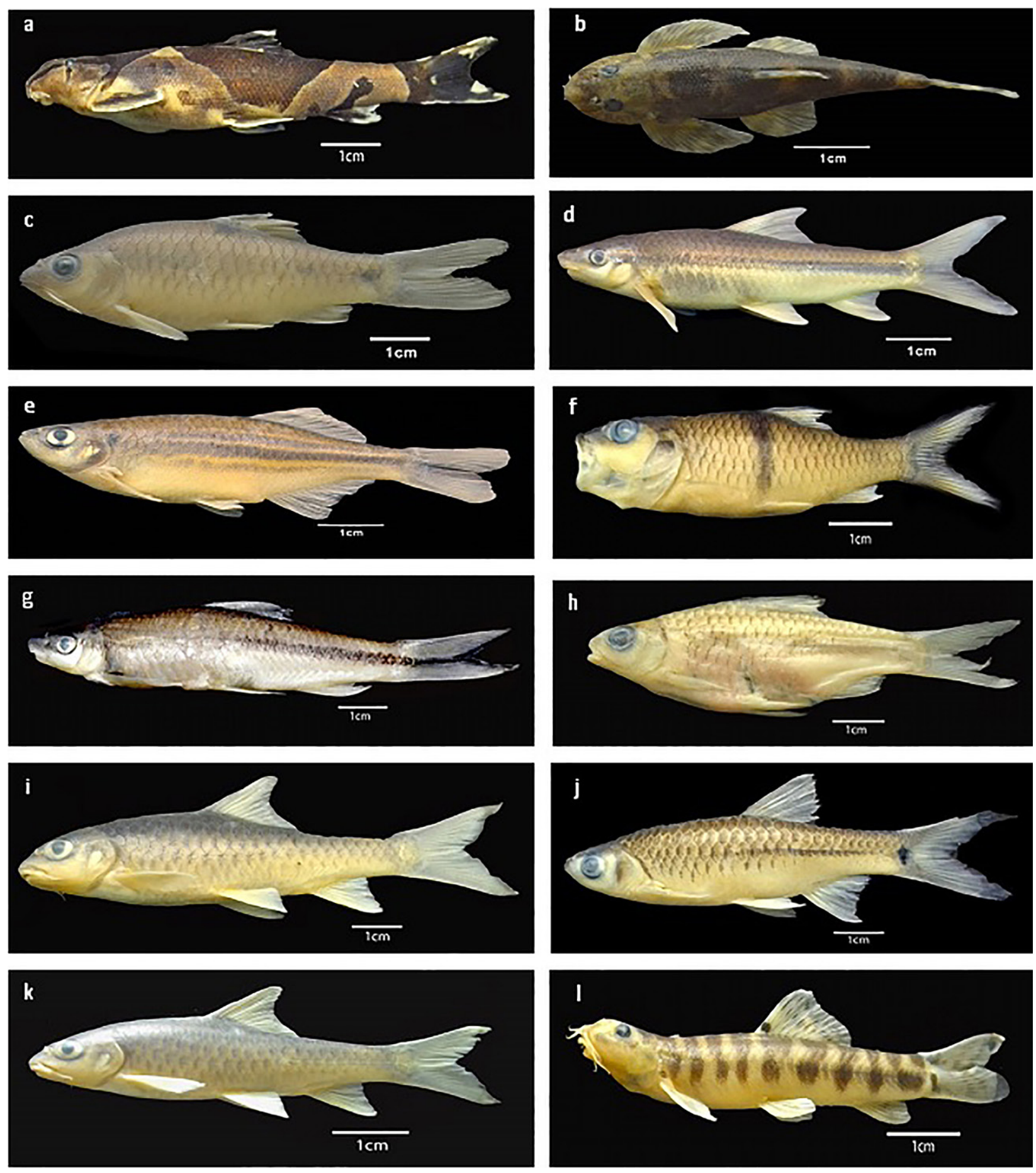

Figure 3. Species sampling in this study: a) Homaloptera orthogoniata (UPMZM F 1001, $82.7 \mathrm{~mm} \mathrm{TL);} \mathrm{b)} \mathrm{Homalopteroides} \mathrm{tweediei} \mathrm{(UPMZM}$ F 1005, 55.0 mm TL); c) Barbodes binotatus (UPMZM F 1010, $73.3 \mathrm{~mm} \mathrm{TL}$ ); d) Crossocheilus atrilimes (UPMZM F 1014, $66.1 \mathrm{~mm} \mathrm{TL);} \mathrm{e)} \mathrm{Devario}$ regina (UPMZM F 1016, $74.1 \mathrm{~mm} \mathrm{TL);} \mathrm{f)} \mathrm{Hampala} \mathrm{macrolepidota} \mathrm{(UPMZM} \mathrm{F} \mathrm{1021,} 77.1 \mathrm{~mm} \mathrm{TL}$ ); g) Lobocheilos bo (UPMZM F 1025, 83.3 mm TL); h) Mystacoleucus marginatus (UPMZM F 1026, $80.0 \mathrm{~mm}$ TL); i) Neolissochilus hexagonolepis (UPMZM F 1029, $100.3 \mathrm{~mm}$ TL); j) Rasbora vulgaris (UPMZM F 1037, 84.0 mm TL); k) Tor tambra (UPMZM F 1043, 55.1 mm TL); I) Nemacheilus masyae (UPMZM F 1047, 66.4 mm TL).

triangular dorsal fin, large anal fin and relatively large, forked caudal fin. Faint stripes are present along the flanks, and there is a small dark blotch behind the eye. The fins may have a reddish tinge. Devario regina can be distinguished from $D$. annandalei and $D$. affinis by the absence of a vertical bars near to the cleithrum. This species usually occurs in flowing streams with sandy bottom (Talwar and Jhingran 1991).
Hampala macrolepidota Kuhl \& van Hasselt, 1823

Hampala macrolepidota Kuhl \& van Hasselt in van Hasselt 1823: 132. Barbus hampal Günther 1868: 139.

Material examined. Table 1; Figure 3f.

Total of 11 soft dorsal-fin rays and eight soft analfin rays; color pattern comprising a dark vertical band originating anteriorly to the dorsal fin and extending below the lateral line plus the presence of black marginal 
stripes in both lobes of the caudal fin (vs unique dark blotch on the body, and inconspicuous marginal stripes on the caudal lobes in $H$. dispar). Hampala macrolepidota occurs mainly in clear rivers or streams with running water and sandy to muddy bottoms (Talwar and Jhingran 1991, Kottelat 1998).

Lobocheilos bo (Popta, 1904)

Lobocheilos bo Popta 1904: 199.

Tylognathus boïdes Popta 1906: 119.

Material examined. Table 1; Figure 3g.

It differs from congeners from Java, Sumatra and Borneo (Lobocheilos falcifer, L. lehat, L. schwanenfeldii and L. kajanensis) by having the following unique combination of features: total of 11 soft dorsal-fin rays and $8 \mathrm{soft}$ anal-fin rays; scales on lateral line 30-31 + 3; absence of black blotch on end of caudal peduncle; absence of crescentic mark along posterior edge of scales; 2 barbels, shorter than eye diameter when present; pectoral fin extending to or almost to the pelvic-fin origin; pelvic fin extending to anal-fin origin; dorsal-fin tip reaching behind vertical through anal-fin origin, when folded backwards; scale rows between lateral line and dorsal-fin origin at 5-61/2; and curved sheath edge of lower jaw (Kottelat and Tan 2008). The fish juveniles are common in shallow, fast flowing areas with gravel substrate (Martin-Smith and Tan 1998).

Mystacoleucus marginatus (Valenciennes, 1842)

Systomus marginatus Valenciennes 1842: 472.

Material examined. Table 1; Figure $3 \mathrm{~h}$.

This species is identified by the following combination of characters: $24-26+2$ scales on lateral line; 14 circumpeduncular scale rows; anal fin with a convex distal margin; dorsal fin with black anterior and distal portions; caudal fin with black distal margin; most scales of body with a black, crescent-shaped base. This species can be found at bottom depths of rivers and streams, and inhabits areas with sand or pea-gravel from small streams to large rivers (Rainboth 1996).

Neolissochilus hexagonolepis (McClelland, 1839)

Acrossocheilus hexagonolepis McClelland 1839: 217.

Material examined. Table 1; Figure 3i.

This species is identified by having two gill rakers at upper arm and 8 gill rakers at lower arm on the first gill arch; 27 scales on lateral line; nine dorsal-fin ray with 2 simple rays; 8 ventral-fin rays with 1 simple ray; 14 pectoral-fin rays with 1 simple ray; 6 anal-fin rays with 1 simple ray (Laskar et al. 2013); color pattern having scales coppery colored with a tinge of red above lateral line and fins deeply slate paling towards their margins. Neolissochilus hexagonolepis differs from N. stracheyi by having absence of a lateral black stripe. The adults of $N$. hexagonolepis occur in fast flowing streams and rivers with rocky bottom, mainly in the middle of streams (Menon 1999). They are omnivorous and the adults feed mainly on filamentous green algae, chironomid larvae, crustaceans and water beetles (Ferro and Badagami 1980).
Osteochilus waandersii (Bleeker, 1853)

Rohita waandersii Bleeker 1853: 733.

Labeo soplaoensis Fowler 1934a: 131.

Material examined. Table 1.

This species can be identified by having a welldefined black stripe along the sides from the gill opening to the end of the median caudal rays; 12 or 13 branched dorsal-fin rays; a bright orange or red caudal, dorsal, anal and pelvic fins. This species usually is associated to clear, relatively fast flowing waters, with gravel to stony bottom (Kottelat 1998).

Rasbora vulgaris Duncker, 1904

Rasbora vulgaris Duncker 1904: 181.

Material examined. Table 1; Figure $3 \mathrm{j}$.

Rasbora vulgaris could be identified by the presence of supra-anal pigmentation in the form of a thin elongate streak and a shallow, somewhat a very deep diamondshaped basicaudal blotch (vs supra-anal pigmentation in the form of an ellipsoidal blotch; and a shallow, somewhat triangular basicaudal blotch in R. vulgaris) (Lumbantobing 2014). This species is found in the Malay Peninsula from southernmost Thailand and west Peninsular Malaysia (Liao et al. 2010). It inhabits lowland to mountain streams with muddy-sand to sandy-gravel bottoms, mostly forest covered (Baran et al. 2005).

Tor tambra (Valenciennes, 1842)

Barbus tambra Valenciennes in Cuvier and Valenciennes 1842: 190. Barbus anisurus Roberts 1993: 22.

Material examined. Table 1; Figure 3k.

This species is characterized by median lobe on lower lip very short, with truncate posterior margin, not reaching beyond line passing between corners of mouth in adults, shorter in juveniles; absence of dark longitudinal stripe in adults; and anal fin tip pointed (Kottelat 2001). They can be found in medium-sized to large rivers (Taki 1978).

Nemacheilus masyae Smith, 1933

Nemacheilus masyae Smith 1933: 58.

Material examined. Table 1; Figure 31.

This species have a total of 13 soft dorsal-fin rays and 8 soft anal-fin rays; color pattern consisting of a light background with 12-17 saddles running along the dorsal surface and a black spot on anteriormost dorsal-fin rays at about $1 / 4$ its length. This species inhabits shallow depths of $2 \mathrm{~m}$ or less in rivers and streams, with moderate current and muddy to sandy bottoms, and also occur in forest streams flowing clear and slightly black waters, as well as in turbid waters (Rainboth 1996). It feeds on insect larvae and aquatic invertebrates (Kottelat 1990).

\section{Perciformes}

Channa gachua (Hamilton, 1822)

Ophiocephalus gachua Hamilton 1822: 68.

Ophiocephalus aurantiacus Hamilton 1822: 69.

Material examined. Table 1; Figure 4a.

This species is characterized by the white margin in dorsal, anal and caudal fins; $3-3 \frac{1}{2}$ scales between the lateral line and the base of the anterior dorsal-fin rays; 

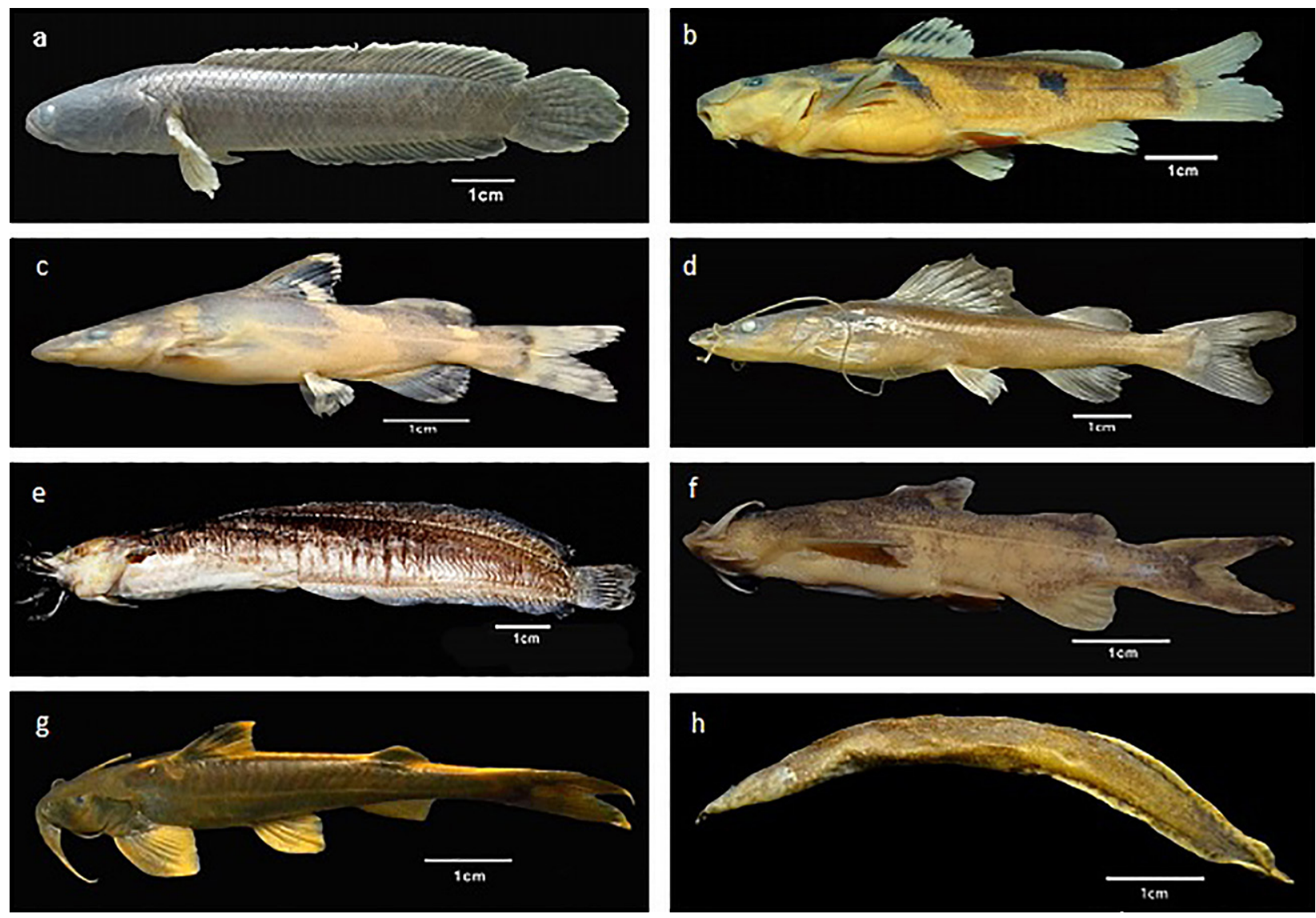

Figure 4. Species sampling in this study: a) Channa gachua (UPMZM F 1049, $94.6 \mathrm{~mm} \mathrm{TL);} \mathrm{b)} \mathrm{Batasio} \mathrm{fluviatilis} \mathrm{(UPMZM} \mathrm{F} \mathrm{1057,} 77.3 \mathrm{~mm} \mathrm{TL);}$ c) Leiocassis poecilopterus (UPMZM F 1061, $78.0 \mathrm{~mm} \mathrm{TL}$ ); d) Mystus cavasius (UPMZM F 1065, $110.0 \mathrm{~mm} \mathrm{TL);} \mathrm{e)} \mathrm{Clarias} \mathrm{leiacanthus} \mathrm{(UPMZM} \mathrm{F}$ 1067, $137.2 \mathrm{~mm} \mathrm{TL);} \mathrm{f)} \mathrm{Glyptothorax} \mathrm{major} \mathrm{(UPMZM} \mathrm{F} \mathrm{1071,} 60.2 \mathrm{~mm}$ TL); g) Glyptothorax siamensis (UPMZM F 1076, $71.2 \mathrm{~mm}$ TL); h) Macrognathus keithi (UPMZM F 1080, $117.0 \mathrm{~mm}$ TL).

relatively small body size, compared to its congeners, such as $C$. orientalis and C. striata. There is significant evidence suggesting C. gachua as a complex of species, and a taxonomic review of this group is clearly necessary. $\mathrm{Ng}$ et al. (1999) noted the presence of small black spots on the body of Indochinese specimens but not on those from India and from Greater Sunda Islands. Notwithstanding, Tan and Ng (2005) later observed this similar color pattern on specimens also from Jambi province, Sumatra. They are usually found in hill streams, while the adults inhabit medium-sized to large rivers, brooks, rapid-running mountain streams, and stagnant water bodies including sluggish flowing canals (Taki 1978). They feed at night on small fish, insects, and crustaceans. They exhibit parental care, with the male brooding eggs and fry in his mouth (Lim et al. 2008)

\section{Channa melasoma (Bleeker, 1851)}

Ophiocephalus melanosoma Bleeker 1856: 214.

Ophicephalus mystax Bleeker, 1853: 188.

Material examined. Table 1.

This species can be distinguished from C. baramensis (former considered a junior synonym of C. melasoma, currently a valid species) by the absence of a black spot in the centre of numerous body scales (vs presence of a black spot in this region) and absence of a barred caudalfin pattern (vs presence of this pattern in specimens larger than $120 \mathrm{~mm} \mathrm{SL}$ ). This species inhabits medium-sized to large rivers (Taki 1978) and occurs in shaded forest streams with sluggish, acidic water, and submerged roots and leaf litter substrates. It also appears to be mainly nocturnal and feeds on small animals (Lim et al. 2008).

\section{Siluriformes}

Amblyceps foratum $\mathrm{Ng} \&$ Kottelat, 2000

Amblyceps foratum $\mathrm{Ng}$ and Kottelat 2000: 338.

Material examined. Table 1.

This species is recognized by having one dorsalfin spine, six soft dorsal-fin rays, $12-15$ soft anal-fin rays, 38-41 vertebrae; posterior edge of adipose fin rounded; adipose-fin base $23.3-27.9 \%$ SL; caudal-peduncle depth $13.2-15.9 \%$ SL; small eyes, dorsolaterally situated and subcutaneous, eye diameter $5.5-8.5 \%$ of head length (HL). This species inhabits rivers and streams with moderate to swift current and sandy or rocky bottoms. They hide under rocks or submerged logs during the day and come out at night to feed. This species is capable of inflicting a painful sting with its dorsal and pectoral-fin spines, with much swelling and excruciating pain in the afflicted area for several hours ( $\mathrm{Ng}$ and Kottelat 2000).

Acrochordonichthys rugosus (Bleeker, 1846)

Pimelodus rugosus Bleeker 1846: 11.

Acrochordonichthys varius Popta 1904: 189. 
Material examined. Table 1.

This species was identified by having 1 dorsalfin spine, 4 or 5 soft dorsal-fin rays; 8-10 soft anal-fin rays; 35-37 vertebrae; long nasal barbels $6.5-15.6 \%$ of HL; lateral margins of head steeply sloping; convex snout dorsally; adipose fin with angular posterior margin; and pectoral-fin spine with serrations on the posterior edge. Acrochordonichthys rugosus differs from A. falcifer by having the posterior margin of the adipose fin angularshaped (vs rounded) and from $A$. pachyderma by having a dark brown color pattern of body with light brown irregular patches (vs cream color pattern of body). This species inhabits clear, swiftly flowing forested streams and sandy or rocky bottoms and hides under submerged logs or rocks with some leaf litter in the swifter parts of the stream ( $\mathrm{Ng}$ and $\mathrm{Ng} 2001)$.

\section{Batasio fluviatilis (Day, 1888)}

Leiocassis fluviatilis Day 1888a: 805

Mystus stigmaturus Fowler 1934a: 94

Mystus havmolleri Smith 1931: 24.

Material examined. Table 1; Figure 4b.

This species is characterized by having 1 dorsalfin spine, 7 soft dorsal-fin rays, 4 or 5 anal-fin spines, and 8 or 9 soft anal-fin rays. It can be distinguished from all congeners, except by $B$. merianiensis, by having an adult color pattern consisting of a dark oblique predorsal bar and dark spot on the lateral of the body, just ventral to the adipose-fin base. This fish occurs in rivers and streams with moderate to swift current and a predominantly rocky bottom; it is less often in slow-flowing streams with a muddy substrate (Ng and Kottelat 2001).

Leiocassis poecilopterus (Valenciennes, 1840)

Leiocassis poecilopterus Valenciennes 1840: 120.

Leiocassis regani Jayaram 1965: 9.

Material examined. Table 1; Figure 4c.

This species was differs from L. micropogon and L. aculeata by having a slightly compressed head with small mouth at subterminal position; short barbels; maxillary barbels reaching only behind the eye; forked caudal fin; tip of upper and lower lobe pointed and posterior border of anal fin slightly rounded (Saenjundaeng and Vidthayanon 2005). The genus is known only from Sundaic Southeast Asia (Mo 1991).

Mystus cavasius (Hamilton, 1822)

Mystus cavasius Hamilton 1822: 39.

Mystus mukherjii Ganguly and Datta 1975: 439.

Material examined. Table 1; Figure 4d.

Species of Mystus are small to medium-sized bagrid catfishes occurring in South Asia. This species was identified by having 1 dorsal-fin spine; 7 dorsal-soft rays; no anal-spine and 10-11 anal-soft rays. The species is distinguished from its congeners by having the maxillary barbels extended beyond posteriorly the caudal-fin base in adults, but in young specimen not extended beyond the anal fin. Color is grayish, with a somewhat well-defined mid-lateral longitudinal stripe; dark spot emphasized by a white or pale area along its ventral margin located just anterior to the first dorsal spine. It can be found in tidal rivers and lakes and also in canals, ditches, ponds, and inundated fields (Talwar and Jhingran 1991).

Clarias leiacanthus Bleeker, 1851

Clarias leiacanthus Bleeker 1851: 430.

Phagorus cataractus Fowler 1939: 54.

Material examined. Table 1; Figure 4e.

This species can be distinguished from congeners that occur in this region by a combination of features: smooth pectoral-fin spine, 68-78 dorsal-fin rays, 58-64 anal-fin rays, moderately broad supraoccipital process, and a distinct color pattern of white spots on the sides of the body. This species is common in forested, more pristine habitats than the sympatric C. batrachus, which is usually common in more open, disturbed habitats (Ambak et al. 2010).

Ompok siluroides La Cepède, 1803

Ompok siluroïdes La Cepède 1803: 50.

Wallago krattensis Fowler 1934b: 335.

Material examined. Table 1.

This species is characterized by having 4 soft dorsalfin rays, 54-74 soft anal-fin rays, 2 pairs of barbels; maxillary barbels reaching pelvic fins or anal fins; mandibular barbels diminute, about as long as eye diameter; small eyes covered by skin; dorsal and pelvic fins small; anal fin long; pectoral fins well developed (Taki 1974) and presence of vomerine teeth in 2 patches (Rainboth 1996). The color body is brown, usually marmorated color body with conspicuous round black blotch above pectoral-fin base (Kottelat 2001). Ompok siluroides differs from $O$. bimaculatus by having rounded head and a mottled brown coloration of the body (vs sharped head, and gray coloration of the body). This species inhabits streams and rivers of all sizes with currents ranging from sluggish to moderate; it moves into freshly inundated habitats during the flood season. These fish feed on crustaceans and mollusks (Rainboth 1996).

Glyptothorax major (Boulenger, 1894)

Akysis major Boulenger 1894a: 246.

Glyptosternum tiong Popta 1904: 191.

Glyptosternum kükenthali Steindachner 1901: 448.

Material examined. Table 1; Figure 4f.

Glyptothorax major differs from congeners from Sundaland, except by G. amnestus, G. decussatus and $G$. plectilis, by having anteromedial striae in the thoracic adhesive apparatus (vs absence of striae). It is further distinguished from G. amnestus and G. decussatus by having slender caudal peduncle $7.7-10.1 \%$ SL (vs 10.3-10.9\% and $9.8-11.2 \%$ SL, respectively), and from G. decussatus by lacking a faint, pale band around the caudal peduncle (vs presence of such color pattern). Additionally distinguish from G. amnestus and G. plectilis by having the anterolateral edges of the thoracic adhesive apparatus markedly concave (vs straight and convex, respectively), and from G. plectilis by a larger head $27.2-31.3 \%$ SL (vs $25.3-27.9 \% \mathrm{SL}$ ); and non-prominent tubercles of uniform size along the flanks (vs with prominent, and enlarged 
tubercles) (Ng and Kottelat 2016). This species occurs in upland and montane brooks as well as small streams and feeds mainly on aquatic insect larvae (Rainboth 1996).

Glyptothorax siamensis Hora, 1923

Glyptothorax siamensis Hora 1923: 168.

Material examined. Table 1; Figure 4g.

This species differs from $G$. platypogonides by having a fairly uniform color pattern with distinct pale mid-dorsal and midlateral stripes (vs highly mottled coloration without any pale stripes). Glyptothorax siamensis is further distinguished from $G$. dorsalis by the absence of pale nuchal shield (vs presence of a pale nuchal shield) (Ng and Rachmatika 2005).

\section{Synbranchiformes}

Macrognathus keithi (Herre, 1940)

Mastacembelus keithi Herre 1940: 24.

Material examined. Table 1; Figure 4h.

Macrognathus keithi was identified by having 25-29 dorsal-fin spines; 52-61 dorsal-fin soft rays; 23-27 pectoral-fin soft rays; 3 anal-fin spines; 52-61 anal-fin soft rays; $18-25$ scale rows between lateral line and base of the first soft dorsal fin and 2 preopercular spines (Inger and Chin 1962). Macrognathus are distributed throughout most of South and Southeast Asia, and feed on small aquatic insect larvae as well as oligochaetes. This species, as well as innumerous congeners are popular to aquaculture, such as the lesser spiny eel, M. aculeatus and the spot finned spiny eel, M. siamensis (Roberts 1980).

\section{Discussion}

The present study identified 26 fish species. A complete list of collected species in this study compared to the previous studies in nearby area at Perak State (Hashim et al. 2012, Amirrudin et al. 2014, Amirrudin and Zakaria-Ismail 2014) is presented in Table 1. All species herein recorded have already been reported for Malaysia (Ambak et al. 2010), with no observation of invasive fish species. The absence of invasive species might be due to the location of our study area, which is quite isolated from human population and urban development, with the notable exception of a nearby aboriginal village. The lower diversity of species could be perhaps explained by the limitation of electrofishing. However, this method otherwise was very selective and yielded quantitatively workable data at higher latitudes, and reliability of specimens identification immediately after captured (Oliveira et al. 2014).

Several fish species, such as T. tambra, H. orthogoniata, G. major, G. siamensis and H. tweediei, are appreciated for their attractiveness by the locals, while others serve as food source by the aboriginal people in the area, including $H$. macrolepidota, C. melasoma and C. leiacanthus. Furthermore, the occurrence of species such as $N$. hexagonolepis and T. tambra are good indicators of the clean water quality of the area (Rainboth 1996). The results of this inventory study is also quite important especially for the current knowledge and status on the fish species that inhabiting high altitude area of tropical rainforest in this country.

According to the diversity, evenness, and richness indices results we concluded that probably the water flow might be the key factor in characterizing the fish community structures in this area, since these indices increased from the upper to the lower portion of the river as expected. Additionally, the number of species inhabiting fast flowing water at upper and middle portions of the river, such as $N$. hexagonolepis and T. tambra, were dramatically reduced in the lowest portions, which is characterized by slow flowing water. Moreover, species possessing specialized body morphology that are adapted to fast water flow, such as species of Glyptothorax with thoracic adhesive apparatus, and $H$. tweediei with flattened head and body, and depressed belly, were mostly observed in the upper and middle river sites $(\mathrm{Ng}$ and Rachmatika 2005, Kottelat 2012). On the other hand, $B$. fluviatilis, L. poecilopterus and N. masyae, which inhabiting slow-flowing streams, were generally observed in the lower site of the river.

This ichthyofaunal inventory provides important information to the current knowledge of fish that inhabit upper Pelus river basin, and the results from this study also might be helpful to manage, protect and conserve this river basin in a near future.

\section{Acknowledgements}

Financial support was provided by the Ministry of Science, Technology and Innovation, Malaysia (Science Fund Project No.: 04-01-04-SF1784).

\section{Authors' Contributions}

MIME, MNAA, AA, JS, AT, MFI collected the data and identified the fishes; NRJ financially supported the sampling activities.

\section{References}

Ahl E (1937) Neue Süsswasserfische aus dem indischen und malaiischen Gebiet. Zoologischer Anzeiger 11: 113-119.

Alfred ER (1969) The Malayan cyprinoid fishes of the family Homalopteridae. Zoologische Mededelingen 43: 213-223.

Ambak MA, Isa MM, Zakaria MZ, Ghaffar MA (2010) Fishes of Malaysia. Penerbit UMT, Universiti Malaysia Terengganu, Terengganu, 334 pp.

Amirrudin BA, Zakaria-Ismail M (2014) Additional native fish fauna of rivers and streams flowing into Temengor reservoir, Perak, Malaysia. Malayan Nature Journal 66 (4): 407-419.

Amirrudin BA, Fahmi-Ahmad M, Rizal SA (2014) Fish diversity in small streams of Sungkai Wildlife Reserve, Perak, Malaysia. Journal of Wildlife and Parks 29: 13-21.

Baran E, Baird IG, Cans G (2005) Fisheries Bioecology at the Khone Falls (Mekong River, Southern Laos). WorldFish Center, Penang, 84 pp.

Bleeker P (1846) Nieuwe bijdrage tot de kennis der Siluroieden van Java. Drukkerij van het Bataviaasch Genootschap van Kunsten en Wetenschappen, Massachusetts, $12 \mathrm{pp}$.

Bleeker P (1851) Vijfde bijdrage tot de kennis der ichthyologische 
fauna van Borneo met beschrijving van eenige nieuwe soorten van zoetwatervisschen. Natuurkundig Tijdschrift voor Nederlandsch Indië 2: 415-442.

Bleeker P (1852) Nieuwe bijdrage tot de kennis der ichthyologische fauna van het eiland Banka. Natuurkundig Tijdschrift voor Nederlandsch Indië 3: 715-738.

Bleeker P (1853) Nalezingen op de ichthyologische fauna van het eiland Banka. Natuurkundig Tijdschrift voor Nederlandsch Indië 5: 175-194.

Bleeker P (1856) Bijdrage tot de kennis der ichthyologische fauna van het eiland Nias. Natuurkundig Tijdschrift voor Nederlandsch Indië 12: 211-228.

Boulenger GA (1894) Descriptions of new freshwater fishes from Borneo. Annals and Magazine of Natural History (6th series) 13 (75): 245-251.

Cuvier G, Valenciennes A (1842) Histoire naturelle des poissons. Vol. 16. Les Cyprinoïdes. Pitois, Paris, 472 pp.

Day F (1888) Supplement to the fishes of India; being a natural history of the fishes known to inhabit the seas and fresh waters of India Burma, and Ceylon. Williams \& Norgate, London \& Edinburg, 779-816 pp.

Duncker G (1904) Die Fische der malayischen Halbinsel. Jahrbuch der Hamburgischen Wissenschaftlichen Anstalten, 2. Beiheft, Mitteilungen aus dem Naturhistorischen Museum in Hamburg 21: 133-207.

Ferro W, Badagami PR (1980) On the biology of the commercially important fish species of Pokhara Valley (Nepal). Journal of Institute of Science and Technology 1: 237-250.

Fowler HW (1934a) Zoological results of the Third de Schauensee Siamese Expedition, part I. Fishes. Proceedings of the Academy of Natural Sciences of Philadelphia 86: 67-163.

Fowler HW (1934b) Zoological results of the Third de Schauensee Siamese Expedition, part V. Additional fishes. Proceedings of the Academy of Natural Sciences of Philadelphia 86: 335-352.

Fowler HW (1939) Zoological results of the Third de Schauensee Siamese Expedition, part IX. Additional fishes obtained in 1936 Proceedings of the Academy of Natural Sciences of Philadelphia 91: 39-76.

Ganguly DN, Datta NC (1975) A new cat fish of the genus Mystus Scopoli (family: Bagridae) from the vicinity of the Hundru Falls, Bihar, India with comment on the genus Mystus. In: Tiwari KK, Srivastava CB [Eds] Dr. B.S. Chauhan Commemoration Volume 1975. Zoological Society of India, Orissa, 439 pp.

Günther A (1868) Catalogue of the fishes in the British Museum. Vol. 7. British Museum, London,524 pp.

Hamilton F (1822) An account of the fishes found in the river Ganges and its branches. Constable, Edinburgh, 405 pp.

Hashim ZH, Zainuddin RY, Shah ASRM, Sah SAM, Syaiful MM, Mansor M (2012) Fish checklist of Perak River, Malaysia. Check List 8 (3): 408-413. https://doi.org/10.15560/8.3.408

Haslawati B, Chew PC, Rosly H (2007) Checklist of native freshwater fishes of Peninsular Malaysia. Department of Fisheries, Putrajaya, 28 pp..

Herre AWCT (1940) New species of fishes from the Malay Peninsula and Borneo. Bulletin of the Raffles Museum 16: 5-26.

Hora SL (1923) On a collection of fish from Siam. Journal of the Natural History Society of Siam 6: 143-184.

Inger RF, Chin PK (1962) The freshwater fishes of North Borneo. Fieldiana, Zoology 45: 1-268. https://doi.org/10.5962/bhl.title.2957

Jayaram KC (1965) On a new species of fish of the family Bagridae. Bulletin of Systematic Zoology, Calcutta 1 (1): 9-10.

Kottelat M, Tan HH (2008) A synopsis of the genus Lobocheilos in Java, Sumatra and Borneo, with descriptions of six new species (Teleostei: Cyprinidae). Ichthyological Exploration of Freshwaters 19 (1): 27-58.

Kottelat M, Widjanarti E (2005) The fishes of Danau Sentarum National Park and the Kapuas Lakes area, Kalimantan Barat, Indonesia. Raffles Bulletin of Zoology, Supplement 13: 139-173.
Kottelat M (1990) Indochinese nemacheilines. A revision of nemacheiline loaches (Pisces: Cypriniformes) of Thailand, Burma, Laos, Cambodia and southern Viet Nam. Verlag Dr. Friedrich Pfeil, München, $262 \mathrm{pp}$.

Kottelat M (2000) Diagnoses of a new genus and 64 new species of fishes from Laos (Teleostei: Cyprinidae, Balitoridae, Bagridae, Syngnathidae, Chaudhuriidae and Tetraodontidae). Journal of South Asian Natural History 5 (1): 37-82.

Kottelat M (2001) Fishes of Laos. WHT Publications, Colombo, 198 pp.

Kottelat M (2012) Conspectus cobitidum: an inventory of the loaches of the world (Teleostei: Cypriniformes: Cobitoidei). Raffles Bulletin of Zoology, Supplement 26: 1-199.

Kottelat M (2013) The fishes of the inland waters of Southeast Asia: a catalogue and core bibliography of the fishes known to occur in freshwaters, mangroves and estuaries. Raffles Bulletin of Zoology, Supplement 27: 1-663.

Kottelat M (1998) Fishes of the Nam Theun and Xe Bangfai basins, Laos, with diagnoses of twenty-two new species (Teleostei: Cyprinidae, Balitoridae, Cobitidae, Coiidae and Odontobutidae). Ichthyological Exploration of Freshwaters 9 (1): 1-128.

Kottelat M, Whitten AJ, Kartikasari SN, Wirjoatmodjo S (1993) Freshwater Fishes of Western Indonesia and Sulawesi. Periplus Editions, Hong Kong, 221 pp.

La Cepède E (1803) Histoire naturelle des poissons. Tome 5. Plassan, Paris, 803 pp.

Laskar BA, Bhattacharjee MJ, Dhar B, Mahadani P, Kundu S, Ghosh SK (2013) The species dilemma of northeast Indian mahseer (Actinopterygii: Cyprinidae): DNA barcoding in clarifying the riddle. PLoS ONE 8 (1): e53704. https://doi.org/10.1371/journal. pone.0053704

Liao TY, Kullander SO, Fang F (2010) Phylogenetic analysis of the genus Rasbora (Teleostei: Cyprinidae). Zoologica Scripta 39 (2): 155-176. https://doi.org/10.1111/j.1463-6409.2009.00409.x

Lim KKP, Tan HH, Low JKY (2008) Fishes. In: Davison GWH, Ng PKL, Chew HH (Eds) The Singapore Red Data Book: Threatened Plants and Animals of Singapore. 2nd ed. Nature Society, Singapore, $285 \mathrm{pp}$.

Lumbantobing DN (2014) Four new species of Rasbora of the Sumatrana group (Teleostei: Cyprinidae) from northern Sumatra, Indonesia. Zootaxa 3764 (1): 1-25. https://doi.org/10.11646/zootaxa.3764.1.1

Margalef R (1958) Information theory in ecology. General Systems Yearbook 3: 36-71.

Martin-Smith KM, Tan HH (1998) Diversity of freshwater fishes from eastern Sabah: annotated checklist for Danum valley and a consideration of inter- and intra-catchment variability. Raffles Bulletin of Zoology 46 (2): 573-604.

McClelland J (1839) Indian Cyprinidae. Asiatic Researches 19: 217-471.

Menon AGK (1999) Check list—fresh water fishes of India. Records of the Zoological Survey of India, Miscellaneous Publication Occasional Paper 60: 1-366 p.

Mills D, Vevers G (1989) The Tetra encyclopedia of freshwater tropical aquarium fishes. Tetra Press, Morris Plains, NJ, 208 pp.

Mo T-P (1991) Anatomy, relationships and systematics of the Bagridae (Teleostei: Siluroidei) with a hypothesis of siluroidphylogeny. Theses Zoologicae 17: 1-216.

$\mathrm{Ng} \mathrm{HH}$, Kottelat M (2000) A review of the genus Amblyceps (Osteichthyes: Amblycipitidae) in Indochina, with descriptions of five new species. Ichthyological Exploration of Freshwaters 11 (4): 335-348.

$\mathrm{Ng} \mathrm{HH}$, Kottelat M (2001) A review of the genus Batasio (Teleostei: Bagridae) in Indochina, with the description of B. tigrinus sp. n. from Thailand. Revue Suisse de Zoologie 108 (3): 495-511.

$\mathrm{Ng} \mathrm{HH}$, Kottelat M (2007) Batasio feruminatus, a new species of bagrid catfish from Myanmar (Siluriformes: Bagridae), with notes on the identity of B. affinis and B. fluviatilis. Ichthyological Exploration of Freshwaters 18 (4): 289-300.

$\mathrm{Ng} \mathrm{HH}$, Kottelat M (2016) The Glyptothorax of Sundaland: a revsision- 
ary study (Teleostei: Sisoridae). Zootaxa 4188 (1): 1-92. https://doi. org/10.11646/zootaxa.4188.1.1

Ng HH, Ng PKL (2001) A revision of the akysid catfish genus Acrochordonichthys Bleeker. Journal of Fish Biology 58: 386-418. https://doi.org/10.1111/j.1095-8649.2001.tb02260.x

$\mathrm{Ng} \mathrm{HH}$, Rachmatika I (2005) Glyptothorax exodon, a new species of rheophilic catfish from Borneo (Teleostei: Sisoridae). Raffles Bulletin of Zoology 53 (2): 251-255.

Ng HH, Ng PKL, Britz R (1999) Channa harcourtbutleri (Annandale, 1918): a valid species of snakehead (Perciformes: Channidae) from Myanmar. Journal of South Asian Natural History 4 (1): 57-63.

Oliveira AG, Gomes LC, Latini JD, Agostinho AA (2014) Implications of using a variety of fishing strategies and sampling techniques across different biotopes to determine fish species composition and diversity. Natureza \& Conservação 12 (2): 112-117. https://doi. org/10.1016/j.ncon.2014.08.004

Pielou EC (1969) An introduction to mathematical ecology. Wiley, New York, 294 pp.

Popta CML (1904) Descriptions préliminaires des nouvelles espèces de poissons recueillies au Bornéo central par M. le Dr A. W. Nieuwenhuis en 1898 et en 1900. Notes from the Leyden Museum 24 (4): 179-202.

Popta CML (1906) Résultats ichthyologique des voyages scientifiques de M. le professeur Dr A. W. Nieuwenhuis dans le centre de Bornéo (1898 et 1900). Notes from the Leyden Museum 27 (1): 1-304.

Popta CML (1911) Vorläufige Mitteilung über neue Fische von Lombok. Notes from the Leyden Museum 34 (1): 9-16.

Rainboth WJ (1996) Fishes of the Cambodian Mekong. FAO Species Identification Field Guide for Fishery Purposes. FAO, Rome, 265 pp.

Roberts TR (1980) A revision of the Asian mastacembelid fish genus Macrognathus. Copeia 3 (3): 385-391. https://doi.org/10.2307/1444512

Roberts TR (1989) The freshwater fishes of Western Borneo (Kalimantan Barat, Indonesia). Memoirs of the Southern California Academy of Sciences 14: 1-210.

Roberts TR (1993) The freshwater fishes of Java, as observed by Kuhl and van Hasselt in 1820-23. Zoologische Verhandelingen 285: $1-94$.

Schreitmüller W (1935) Barbus simplex Schreitm. (1933) (Silberbarbe), eine neue Art. Nachrichtenblatt für Aquarien-und Terrarienvereine 40: 508.

Shannon CE, Weaver W (1963) The Mathematical Theory of Communication. University of Illinois Press. Urbana, $125 \mathrm{pp}$.

Smith HM (1931) Description of new genera and species of Siamese fishes. Proceedings of the United States National Museum 79 (7): 1-48. https://doi.org/10.5479/si.00963801.79-2873.1

Smith HM (1933) Contributions to the ichthyology of Siam. II. New species of loaches of the genus Nemacheilus. III. A new genus and species of cyprinoid fish. IV. A new goby of the genus Vaimosa. V. A new genus and species of glyptosternoid catfishes. VI. Fishes not previously recorded from Siam. Journal of the Siam Society (Natural History Supplement) 9 (1): 53-87.

Smith HM (1945) The fresh-water fishes of Siam, or Thailand. Bulletin of the United States National Museum 188: 1-622.

Steindachner F (1901) Fische. [In: W. Kükenthal (Ed.) Ergebnisse einer zoologischen Forschungsreise in den Molukken und Borneo. Zweiter Teil: Wissenschaftliche Reiseergebnisse. Band 3]. Abhandlungen der Senckenbergischen Naturforschenden Gesellschaft 25 (2): 409-464.

Taki Y (1974) Fishes of the Lao Mekong Basin. United States Agency for International Development Mission to Laos Agriculture Division, $232 \mathrm{pp}$.

Taki Y (1978) An analytical study of the fish fauna of the Mekong basin as a biological production system in nature. Research Institute of Evolutionary Biology Special Publications No 1. Research Institute of Evolutionary Biology, Tokyo, 77 pp.

Talwar PK, Jhingran AG (1991) Inland fishes of India and adjacent countries. Vol 1. A.A. Balkema, Rotterdam, 541 pp.

Tan HH, Ng PKL (2005) The labyrinth fishes (Teleostei: Anabanatoidei, Channoidei) of Sumatra, Indonesia. Raffles Bulletin of Zoology, Supplement 13: 115-138.

Toriman ME (2010) Assessing environmental flow modeling for water resources management: a case of Sg. (River) Pelus, Malaysia. Nature and Science 8 (4): 69-76.

Toriman ME, Jaafar M, Abdullah SMS (2008) Environmental flow modelling as a tool for water resources management: a study of detailed Environmental Impact Assessment (DEIA) in Sungai Pelus River catchment, Malaysia. Journal of Social Sciences and Humanities 3 (1): 1-10.

Vaillant L (1902) Résultats zoologiques de l'expédition scientifique néerlandaise au Bornéo central. Notes from the Leyden Museum 24: 1-166.

Valenciennes A (1842) Les poissons. Vol. 4. In: Cuvier G. (Ed.) Le règne animal distribué $\mathrm{d}$ 'après son organisation, pour servir de base à l'histoire naturelle des animaux et d'introduction à l'anatomie comparée. Edition accompagnée de planches gravées, représentant les types de tous les genres, les caractères distinctifs des divers groupes et les modifications de structure sur lesquelles repose cette classification; par une réunion de disciples de Cuvier, Mm. Audoin, Blanchard, Deshayes, Alcide d'Orbigny, Doyère, Duvernoy, Laurillard, Milne Edwards, Roulin et Valenciennes. Fortin, Masson \& Cie, Paris, 392 pp. https://doi.org/10.5962/bhl.title.49223

van Hasselt JC (1823) Uittreksel uit enn' brief van den Heer J. C. van Hasselt, aan den Heer C. J. Temminck, geschreven uit Tjecande, Residentie Bantam, den 29sten December 1822. Alg Konst- en Lett voor het Jaar 1823 (2): 130-133.

Zulkafli AR, Asmuni M, Hassan AG, Haslawati B (2014) Ikan-ikan air tawar Sungai Pahang (Freshwater fishes of Pahang River). Department of Fisheries, Putrajaya, 62 pp. 